\title{
Metáforas metalinguísticas de Euclides da Cunha
}

\author{
Metalinguistic Metaphors of Euclides da Cunha
}

\section{Carlos Antônio Magalhães Guedelha}

Universidade Federal do Amazonas - UFAM-AM - Manaus - Amazonas - Brasil

\begin{abstract}
Resumo: Este artigo apresenta uma leitura das metáforas metalinguísticas do escritor Euclides da Cunha, ou seja, as metáforas que ele utilizou para se referir aos seus dois principais livros, Os Sertões (sobre a guerra de Canudos) e Um paraíso perdido (sobre a Amazônia). O conceito de metalinguagem estabelecido por Jakobson foi fundamental para a pesquisa, que teve como suporte teórico básico o postulado da metáfora conceptual, proposta por Lakoff e Johnson (2002). As metáforas analisadas neste artigo (VINGAR-SE É ESCREVER e UM LIVRO É UM FILHO) foram colhidas de ensaios do escritor e de cartas que ele escreveu a amigos e familiares, "escriturando" a sua escrita por meio da metalinguagem. As reflexões sobre as metáforas assume, com base em Lakoff e Johnson (2002), que a metáfora não é uma questão apenas de linguagem. Ela é também - e fundamentalmente - uma questão de pensamento e ação. As reflexões recorrem a Mota (2003), que também comenta os textos de Euclides.
\end{abstract}

Palavras-chave: Metalinguagem. Metáfora. Euclides da Cunha. Escrita.

Abstract: This paper presents a reading of the metalinguistic metaphors used by Euclides da Cunha, to refer to his two main books, Os sertões (about The Canudos' War) and Um paraíso perdido (about Amazonia). The concept of the metalanguage established by Jakobson was fudamental to the research, which had $s$ its basictheoretical support of Lakoff and Johnson's conceputal metaphor postulate (2002). The metaphors analyzed in this paper (TO REVENGE IS TO WRITE and BOOK IS A $\mathrm{SON}$ ) were collected from the writer's essays and letters he wrote to friends and family, rewriting his writing through the metalanguage. Based on Lakoff and Johnson (2002), the reflections assumes that metaphor is not just a matter of language. It is also - and fundamentally - a matter of thought and action. The research uses Mota (2003), which also comments Euclid's texts.

Keywords: Metalanguage. Metaphor. Euclides da Cunha. Writing. 


\section{Introdução}

Este artigo trata da escrita metalinguística de Euclides, em que ele metaforiza sua produção literária, em cartas que escreveu a amigos e em artigos e ensaios publicados. Reflito aqui a respeito da atitude do autor em operar a "escrituração" de sua escrita, para utilizar um termo de Gilberto Mendonça Teles (1996).

Foi Jakobson quem primeiro discorreu com clareza sobre a função metalinguística da linguagem, que traz a própria linguagem para o primeiro plano da cena enunciativa. No ensaio intitulado Linguística $e$ poética, Ele diferencia a "linguagem-objeto, que fala de objetos, e a metalinguagem, que fala da linguagem" (JAKOBSON, 2010, p. 162). Assim ele estabeleceu a função metalinguística como aquela em que a linguagem é empregada para falar de si mesma.

Chalhub (2002, p. 32), comentando o que disse Jakobson, observa que "a função metalinguística centraliza-se no código: é código 'falando' sobre o código. É linguagem 'falando' de linguagem, é literatura sobre literatura, é palavra da palavra". E acrescenta que uma mensagem de nível metalinguístico "implica que a seleção operada no código combine elementos que retornem ao próprio código. [...] Mensagens de perfil metalinguístico operam, portanto, com o código e o presentificam na mensagem" (CHALHUB, 2002, p. 49).

Portanto, a linguagem se encontra em função metalinguística quando discorre sobre ela própria. Nesse caso, a própria linguagem é posta em questão. O autor lança mão do código linguístico para transmitir suas reflexões sobre esse mesmo código. Em outras palavras, a própria linguagem é questionada e posta em destaque. E o emprego da função metalinguística na literatura põe em evidência a própria criação artística.

Pela ferramenta da metalinguagem, o autor apresenta-se ao interlocutor ou leitor ao mesmo tempo como criador e como crítico de sua obra. $O$ artista mostra-se como construtor e usuário de uma linguagem. Roland Barthes (1970) vê na literatura um duplo movimento de sentido, tendo em vista que ela fala do mundo e fala de si mesma, ao mesmo tempo, e dessa forma torna-se literatura-objeto (ou linguagem-objeto, aquela que se estuda) e metaliteratura (ou metalinguagem, aquela com que se estuda, linguagem instrumental). A metalinguagem, de caráter crítico-analítico, possibilita estudar a linguagem-objeto sem com ela se confundir. Por esse viés, a metalinguagem na literatura é capaz de despertar no leitor a consciência do fazer artístico (processo) que redunda na obra de arte (produto).

Euclides da Cunha parece não abrir mão da ferramenta da metalinguagem em seus escritos. Ele foi um severo (aliás, muito severo) crítico de si mesmo, de seus próprios textos, como se pode perceber nos exemplos que cito na sequência deste capítulo. E essa sua severidade o levava frequentemente a planejar a sua escrita com o rigor avaliativo do engenheiro. Depois do planejamento, vinha a execução, que consistia em escrever. Mas o processo não parava aí: depois da escrita, vinha a "escrituração" dessa escrita. O termo "escrituração", que aqui utilizo, foi tomado de empréstimo à área contábil e aplicada à literatura por Teles (1996) para comparar a atividade crítica com a arte de escriturar os livros comerciais ou contábeis, tomando por base, especialmente, as personagens contabilistas de Graciliano Ramos, que viviam às voltas com a "escrituração" de sua escrita. Assim é que tomamos contato com a escrituração que Euclides fazia de seus próprios escritos, no decurso desses escritos ou nas cartas que enviou a amigos e familiares. E no âmago dessa autoavaliação brotam as duas expressivas metáforas sobre as quais reflito aqui: VINGAR-SE É ESCREVER e UM LIVRO É UM FILHO.

\section{Metáfora "Vingar-se é Escrever"}

Euclides chamou seus dois grandes livros - Os Sertões e Um Paraíso perdido - cada um a seu tempo, de "meu livro vingador". Em que consistia essa metáfora? A que vingança se referia em cada 
caso? É essa questão que procuro responder nos subitens que seguem.

\subsection{0 primeiro "livro vingador"}

Júlio Mesquita, que era editor do jornal Estado de São Paulo, ao convidar Euclides para a tarefa de fazer a cobertura da guerra de Canudos, tinha convicção de que estava apostando na pessoa certa para o projeto que tinha em mente: queria mais que um relato jornalístico bem elaborado. Pretendia receber das mãos do correspondente uma análise aprofundada das causas e consequências daquela guerra. Para tanto, necessitava de alguém que tivesse capacidade de realizar a tarefa completa, nesses termos. E Euclides era a pessoa mais indicada (MOTA, 2003).

Recebendo e aceitando o convite, Euclides começou a se preparar para a empreitada. Após conseguir uma licença do seu trabalho na Superintendência de Obras Públicas de São Paulo, transferiu a família para a fazenda de seu pai, no município de Belém do Descalvado, e passou a recolher o máximo de informações possíveis sobre a região para onde teria que ir em missão.

Partiu para a Bahia no dia 4 de agosto de 1897, como adido do Estado-Maior do ministro da guerra. Em viagem, escreveu para o sogro, general Solon, em 12 de agosto, falando sobre o seu intento:

\begin{abstract}
A minha missão é esta: fui convidado em São Paulo para estudar a região de Canudos e traçar os pontos principais da Campanha. Aceitei-a e vim. Além do assunto ser interessante, além de estar em jogo a felicidade da República, considereis que tínheis um nobre papel em tudo isto e almejo defini-lo bem perante o futuro. Consegui-lo-ei? Anima-me a intenção de ser o mais justo possível; porei de lado todas as afeições para seguir retilineamente" (in: GALVÃO; GALOTTI, 1997, p. 107).
\end{abstract}

Foi movido por esse ideal de justiça que chegou a Salvador, onde se viu obrigado a passar vinte e quatro dias antes de partir para Canudos, tendo em vista os sucessivos adiamentos da partida da tropa por questões operacionais. $\mathrm{Na}$ ansiedade desse período extenuante de quase um mês, aproveitou para colher mais informações sobre a realidade do conflito, ouvindo os relatos $e$ testemunhos dos que regressavam do campo de batalha quase diariamente. Juntando esses relatos e testemunhos, pôde começar a montar um quadro mais realista da situação.

Nesse período também enviava suas interpretações do conflito para o jornal. Nesses artigos que enviava para São Paulo, assim como em sua correspondência ativa, é possível perceber a evolução do seu pensamento em relação à guerra. Nos primeiros textos ainda se pode ver um Euclides cheio de brios republicanos, disposto a desmascarar um grande foco de conspiração monarquista. Era a mesma postura de quando escrevera estas palavras ao amigo João Luís, em abril de 1897, a respeito da guerra: "O que me impressiona não são as derrotas são as derrotas sem combate - em que o chão fica vazio de mortos e o exército se transforma num bando de fugidos" (in: GALVÃO; GALOTTI, 1997, p. 105). Agora, cinco meses depois, estando já em terra baiana, lamentava muito os entraves que 0 mantinham preso à capital. "Temo não poder ir a tempo de assistir a queda do arraial maldito" (in: GALVÃO; GALOTTI, 1997, p. 108), escreveu ao amigo Porchat, de Salvador, em 20 de agosto de 1897.

Mas a sua visão vai se modificando paulatinamente, à medida que "pesquisa, estuda, entrevista, visita os hospitais em companhia de altos oficiais do Exército [...] e em que observa, nas estações de estrada de ferro, a chegada dos feridos em combate" (MOTA, 2003, p. 96). Começou a perceber que olhar o Conselheiro como um simples inimigo da República, um ardiloso aliado dos conspiradores monarquistas era um lamentável equívoco e um grande exagero.

Canudos marcaria a vida de Euclides. Em meio às aspirações republicanas que acalentava, apesar de não ter naquela república a República dos seus sonhos, Canudos surgiu como uma surpresa e o acordou para uma realidade que ele não supunha existir. "Lá compreendera melhor o Brasil, na sua 
realidade física e social. As ilusões e os enganos, que eram da sua geração e que eram seus, desfizeram-se para sempre" (RABELLO, 1966, p. 137).

Apenas dois meses que Euclides passou em Canudos foram suficientes para transformá-lo em outro homem: a tragédia que presenciara pesou fundo em sua alma, porque foi capaz de perceber o sentido humano daquele episódio que para muitos era aparentemente insignificante. Reavaliara o seu posicionamento sobre o confronto, e o seu juízo sobre o Conselheiro e sobre a campanha do exército em Canudos já não era o mesmo. Via a guerra como um encontro fatídico e fratricida entre dois brasis que se desconheciam, o do litoral (desenvolvido) e o do sertão (atrasado, retrógrado). Foi um amadurecimento forçado. "Como na transição das idades, ele voltou de Canudos em verdadeira crise. Despojara-se dos resíduos do passado com a mesma misteriosa tristeza dos adolescentes na antemanhã da vida livre e já grave, dos vinte anos" (RABELLO, 1966, p. 138).

Mota (2003, p. 109) anota que

Daquela campanha, da sua observação cuidadosa, vai surgir uma obra-prima da literatura brasileira. Mas não apenas da literatura. Os Sertões, que Euclides a rigor já começara a escrever, sendo os comentários enviados ao Estado o seu embrião, será muito mais que uma obra-prima literária. Esse "livro vingador", prodígio de síntese de literatura, sociologia, geografia, climatologia, botânica, geologia, economia e história, será um grito de alerta às descuidadas e frívolas elites do litoral para a necessidade de se lembrarem das injustiçadas e esquecidas populações do sertão e incorporá-las à civilização.

Referindo-se a Os Sertões, Rabello (1966, p. 140) comenta que o livro "já estava maduro desde o tempo em que escrevera o Diário de uma expedição", enquanto ainda se encontrava na Bahia. Na verdade, aquele diário continha, em anotações meticulosas sobre a região, um farto material que era o embrião do livro a ser escrito.

Mas ao retornar da Bahia, Euclides jamais pôde dedicar-se à escrita do seu livro como gostaria de fazê-lo. A "obscura" profissão de engenheiro, que ele tanto maldizia em cartas a amigos e parentes, sobrecarregava-o de afazeres e preocupações, não
Ihe reservando o tempo necessário para o prazer das letras. Dessa forma, Os Sertões foram escritos "à prestação", nas "brechas" de tempo da sua engenharia fatigante e obscura, como confidenciou em carta ao amigo José Veríssimo. Em lamentação semelhante, diz a outro amigo, Pethion de Villar, em maio de 1900:

Levo a mais inútil das vidas em perene conflito com a minha engenharia obscura cujas exigências me afastam de outras ocupações mais atraentes às quais somente dedico um ou outro quarto de hora de folga nos meus dias fatigantes de operário. Por isto o meu livro sobre a interessantíssima luta nos sertões da tua terra ainda não apareceu. Está, porém, agora, - finalmente, pronto e ainda que seja o primeiro a considerá-lo lardeado de defeitos sérios entre os quais avulta certa falta de unidade oriunda das condições em que foi escrito - tem, preponderante, uma qualidade que o nobilita: a sinceridade com que foi traçado. Será seu único valor. Por isto, talvez não faça jus à consagração de uma versão para o francês a que espontânea e cavalheirescamente te propuseste quando aí estive. Transplantado para a mais vibrátil das línguas, por um parisiense dos trópicos, temo que meu estilo, algo bárbaro, não se afeiçoe a tão delicado relevo (in: GALVÃO; GALOTTI, 1997, p. 118).

Nessa carta, Euclides - além de dar curso à constante lamúria a respeito da falta de tempo para se dedicar à ocupação mais atraente das letras por força da sua engenharia obscura - revela duas preocupações sobre o seu livro que, até a consagração do mesmo, serão também constantes: os erros que o livro porventura continha e a dúvida sobre o seu real valor e sua aceitação. Ressalte-se aí a metáfora metalinguística, na verdade uma antítese, através da qual Euclides contrapõe a "delicadeza" da língua francesa ao seu estilo em Os Sertões, que considera "bárbaro" (bruto).

Em 1901 terminou a feitura do livro. Com ele, propôs "vingar-se da chacina dos sertanejos feita pelas tropas do governo, que se haviam batido bravamente, mas que haviam sido também incapazes de se libertarem de uma série de mal entendidos e preconceitos, e de reconhecerem e recompensarem o heroísmo dos jagunços" (MOTA, 2003, p. 118). É o que ele diz quando escreve a Francisco Escobar em abril de 1902: 
Alenta-me a antiga convicção de que o futuro - lerá. Nem outra coisa quero. Serei um vingador e terei desempenhado um grande papel na vida - o de advogado dos pobres sertanejos assassinados por uma sociedade pulha, covarde e sanguinária... Além disto terei o aplauso de uns vinte ou trinta amigos em cuja primeira linha estás. E isto me basta." (in: GALVÃO; GALOTTI, 1997, p. 133)

Ao deixar São José do Rio Pardo, Euclides tinha duas obras em que apostou a sua reputação no futuro: o livro e a ponte que construíra sobre o rio Pardo. A reputação de escritor e a reputação de engenheiro. Poder-se-ia dizer que, na verdade, tratava-se de duas engenharias, a civil e a literária.

Antes de procurar um editor para o livro recém-escrito, ele remenda várias passagens do texto, corrige erros ortográficos, repara, retoca, emenda. Revela, assim, uma demasiada vigilância em torno da intocabilidade linguística da obra. Era o escritor "escriturando" a sua escrita.

Depois viria a difícil tarefa de encontrar uma editora disposta a publicar o livro de um "desconhecido" e com o número de páginas que ele tinha. Porque antes de se tornar um "grande livro", Os Sertões era, seguramente, para os padrões da época, um "livro grande". Rabello (1966) informa que Euclides chegou a pensar em publicá-lo em forma de colunas no Estado de São Paulo, parceladamente. Imaginava que assim poderia atrair o interesse de alguma editora.

Foi pensando em pôr em ação essa estratégia que entregou os originais ao redator Júlio Mesquita, que os deixou empoeirando na estante da redação. Depois de muito andar de um lado para o outro com seu calhamaço de manuscritos, Euclides conseguiu, com a intervenção de amigos, que a Editora Laemmert - com uma certa relutância resolvesse publicá-lo.

Considero que, ao metaforizar essa obra como um "livro vingador", Euclides estava externando uma metáfora conceptual que estava na base de sua concepção a respeito daquela obra e dos fatos que ela apresentava. Cheguei a esta conclusão baseado no fato de que, para a teoria da metáfora conceptual, determinadas metáforas na linguagem refletem determinadas metáforas no pensamento (LAKOFF e JOHNSON, 2002). Assim sendo, parece certo entender que a escrita daquele livro tinha, de verdade, no pensamento de Euclides, o valor de uma vingança.

Vexado, decepcionado e extremamente revoltado com o que presenciara no arraial de Canudos, ele tinha naquele momento corrigido o seu ponto de vista. Não mais via Canudos como um foco monarquista, no entanto via a campanha do Exército ali como um crime. O mesmo Exército que antes fora visto como brioso por abafar o "levante". Havia prometido vingar os sertanejos desse horrendo crime, um massacre. E a vingança foi o livro que veio à luz, Os Sertões.

Detectamos, por meio da expressão linguística "livro vingador", a metáfora da escrita como vingança que subjaz a essa expressão. O escritor transita do terreno concreto, do observável (vingarse), em direção a um campo mais abstrato (escrever), guiado pela metáfora de base VINGAR-SE É ESCREVER. Isso significa que as metáforas conceptuais subjazem às expressões linguísticas metafóricas. A forma como Euclides organizou o seu dizer nesse recorte textual pode comprovar que foram organizados diferentes domínios de sua experiência para fazer entender o mundo e dele construir o sentido. No domínio-fonte da escrita, ele projetou o domínio-alvo da vingança, fazendo pensar a vingança em termos de escrita. Isso confirma a hipótese de Lakoff e Johnson (2002) de que o uso da metáfora é uma questão do processo do pensamento e da ação humana, e não apenas um requisito da linguagem.

\subsection{0 segundo "livro vingador"}

Observamos padrões metonímicos na formação de adjetivos e de verbos. Em relação à formação de substantivos, faremos algumas considerações na seção 2.3, "Discussão".

\subsubsection{Metonímia na formação de adjetivos}


Rabello (1966) informa que dois fatores conjugados determinaram a intensa migração das populações sertanejas para a Amazônia em fins do século XIX e princípios do século $X X$ : as secas fustigantes e a exploração extensiva da borracha natural da seringueira. Consequentemente, as fronteiras amazônicas foram sendo expandidas para além dos limites estabelecidos na época. Mota (2003, p. 154) complementa

Este movimento que as populações sertanejas, fustigadas pelas secas, fazem em direção à região amazônica, em busca da riqueza da borracha, marca a última etapa da expansão territorial brasileira que, após o acordo com a Bolívia - que nos deu o Acre e com o Peru, que delimitou com precisão, e definitivamente, as nossas linhas de fronteira nos confins da Amazônia, o Brasil adquire a feição que conserva até hoje. Os nordestinos, fugindo da miséria de suas terras, completam assim, alguns séculos depois, a missão dos bandeirantes.

No entanto, esse processo não se completa sem choques. Pelo contrário, como nos lembra Mota (2003, p. 154),

esses choques vão da luta armada às renhidas disputas diplomáticas com o Peru e a Bolívia, conduzidas, do lado brasileiro, pelo Barão do Rio Branco. O conflito com países vizinhos da América Espanhola fora evitado em grande parte em função do gênio negociador de Rio Branco. Em termos de política externa, os elementos que dominam a cena no Brasil, em fins do século passado e começos do atual, são justamente as disputas de fronteira com aqueles vizinhos - Bolívia e Peru.

A migração para o Acre torna-se mais acentuada por volta de 1870. Imensas levas de cearenses abandonavam suas terras no Nordeste para se transformarem em seringueiros, principalmente em terras acrianas. Rabello (1966) comenta que na época o Acre era considerado uma terra sem dono. Mas a verdade era bem outra: formalmente o Acre não era terra de ninguém, pois embora seus contornos fossem imprecisos, "a soberania formal sobre a maioria de sua área era da Bolívia, com o Peru diretamente interessado na questão, pois também esse país ainda não havia na época determinado com precisão as fronteiras que 0 separam do Brasil na Amazônia" (MOTA, 2003, p. 155).

Mas aquela era uma região relativamente esquecida, abandonada. "Os dois países apenas se lembraram de reclamar os direitos sobre ela quando, em 1867, o Amazonas foi aberto à navegação estrangeira, ligando aquela região abandonada ao Atlântico. Subitamente perceberam todos o seu valor". Com a descoberta das seringueiras nativas da região, as disputas pela terra recrudesceram. "Dentro em pouco, a borracha tirada das seringueiras atingiria preços altíssimos no mercado internacional, transformando a região antes abandonada e relegada ao esquecimento numa das mais potencialmente ricas de toda a América do Sul" (MOTA, 2003, p. 155).

No ano de 1867 foi assinado, entre o Brasil e a Bolívia, um protocolo que previa a demarcação precisa dos limites. Mas enquanto a demarcação se demorava, os nordestinos, que não tinham a mínima noção de pendências fronteiriças entre países, iam ocupando aquela área em litígio na sua quase totalidade. Como a demarcação das fronteiras se fazia demorar, em 1902 os bolivianos decidiram entrar em ação e ocupar a região, mas foram expulsos pelos brasileiros - armados e treinados pelo gaúcho Plácido de Castro. No ano seguinte o caudilho gaúcho assentaria as bases do Estado Independente do Acre. Num espaço onde os ânimos se acirravam cada vez mais, os enfrentamentos não tinham pausa enquanto as negociações diplomáticas eram ativadas, em busca de um acordo amigável.

A extração da borracha criara um clima de febril agitação, pois era uma riqueza imensa que nenhum dos dois países queria deixar entregue ao outro. O Acre era, então, um dos maiores produtores mundiais do látex oriundo da seringueira. Os conflitos e as batalhas diplomáticas foram se sucedendo até 1903, quando foi assinado o Tratado de Petrópolis. Pelo Tratado, o Acre foi definitivamente incorporado ao Brasil, que por ele pagou de 2 milhões de libras esterlinas à Bolívia, além de outras compensações em territórios e no compromisso de construir a 
estrada de ferro Madeira-Mamoré (GONDIM, 1994; REIS, 1998; SOUZA, 2009).

Por esses tempos, ainda segundo Rabello (1966), o Peru pleiteava junto ao governo brasileiro a posse de uma grande faixa de terra entre o rio Madeira e o rio Javari. Ali também havia enfrentamentos constantes entre brasileiros e peruanos. Desde 1902, tropas peruanas haviam ocupado os vales do Juruá e do Purus para dar apoio aos seus compatriotas. O Brasil também envia tropas para proteger os brasileiros. O Barão do Rio Branco intervém, pondo em ação mais uma vez a sua grande habilidade como negociador (RABELLO, 1966; MOTA, 2003).

Mota (2003, p. 157) relata que em 1904 os dois governos assinaram um convênio prevendo um prazo de cinco meses para a solução do problema.

\begin{abstract}
Durante esse tempo, o território em litígio ficaria sob a proteção de uma força mista brasileiro-peruana. Reconhece-se, por esse convênio, que o princípio do uti possidetis será aplicado ao território em litígio, ocupado por brasileiros ou peruanos, numa solução equitativa: quem ocupa efetivamente a terra ganha a soberania sobre ela. Mas, tratandose de regiões quase desconhecidas, é necessário, antes de chegar a um acordo definitivo, estudá-las melhor, fazer o trabalho de reconhecimento das cabeceiras do alto Juruá e do alto Purus.
\end{abstract}

Foi esse quadro beligerante, foi esse clima dominante da política externa brasileira no ano de 1904 que despertou a atenção e o interesse de Euclides, que vivia então a desagradável situação de engenheiro desempregado, apesar da fama que o seu primeiro livro, Os Sertões, the propiciara. Euclides, na verdade, nunca tivera um emprego fixo, e sua família sofria muitas privações. E assim, as notícias dos acirramentos na Amazônia o encontram na grande fila dos engenheiros desempregados (RABELLO, 1966).

Ainda em 1904, ele escreveria três artigos para o Estado de São Paulo tratando da questão: "Conflito inevitável", "Contra os caucheiros" e "Solidariedade sul-americana".

Para levar a efeito o acordo firmado no Tratado de Petrópolis, o Ministério das Relações
Exteriores criou duas comissões de reconhecimento, uma do Juruá e outra do Purus. Euclides valeu-se de amigos influentes para conseguir se integrar a uma dessas comissões. Ele já manifestara interesse pela Amazônia anteriormente. Quais as razões para esse interesse? Resolver seu problema de engenheiro desempregado; vontade de fugir dos problemas que o atormentavam na cidade grande; fascínio que sentia pela região, e tudo isso junto (RABELLO, 1966; MOTA, 2003).

Depois da nomeação conseguida, em confissão a amigos (Oliveira Lima e José Veríssimo, por exemplo), Euclides esclarecia com todas as letras o seu objetivo: "estudar a região e o povoamento que ali se faz, para uma outra obra que, à semelhança de Os Sertões, revele ao Brasil mais um pedaço de si mesmo". Ele "Sente que ainda pode fazer muito. É relativamente jovem e o grande êxito de Os Sertões constitui um desafio, a suplantar para não se transformar no autor de um só livro, para provar que o talento nele não é coisa episódica, que floresceu apenas uma vez, como por acaso" (MOTA, 2003, p. 159). Ele sabia que ali estava sua segunda oportunidade de produzir uma grande obra; a primeira acontecera com Os Sertões.

Euclides ficou surpreso ao saber que Rio Branco lhe dera não apenas o posto de simples de auxiliar, mas a chefia da comissão de reconhecimento do alto Purus, que deveria ser dividida com o peruano Pedro Buenaño, enquanto a chefia da comissão de reconhecimento do alto Juruá fora entregue ao coronel Belarmino de Mendonça, a ser dividida com o capitão peruano Felipe Espuiar (RABELLO, 1966; MOTA, 2003).

Euclides deixou a família no Rio de Janeiro e partiu para o Amazonas em 13 de dezembro de 1904, chegando no dia 30 desse mês a Manaus, onde passaria três meses hospedado na casa do amigo Alberto Rangel. Uma vez na capital amazonense, ele ficou muito irritado com os embaraços burocráticos e a má vontade de funcionários que deveriam ajudá-lo. Preso numa cadeia de morosidades, sentia-se extenuado (RABELLO, 1966). 
Partiu no dia nove de abril rumo às cabeceiras do Purus. A certa altura da viagem, a comissão sofre um acidente em que perdem a embarcação de provimentos para a alimentação. Passam fome e privações no restante da viagem, submetidos a um severo regime de racionamento. Realizam a tarefa e voltam extenuados, irreconhecíveis.

Euclides agiu, em toda a viagem, como um atento observador que tudo anotava, num grande esforço para não deixar passar despercebido o menor detalhe que fosse dos flagrantes que observava. Dessa observação atenta e prolongada ele projetava escrever um livro dando conta do que vira. Após sua passagem pela região, a escrita do livro não era mais encarada como apenas um projeto, mas sim como uma obrigação moral, semelhantemente ao caso de Canudos.

A situação de abandono e miséria absoluta das populações com as quais contactara no interior da Amazônia o deixaram revoltado, comovido "e, tal como em Canudos, tomou como missão, num segundo 'livro vingador', denunciar o fato à Nação, e reclamar do governo medidas em favor dos sertanejos que, transformados em seringueiros, garantiam para o Brasil a posse de regiões riquíssimas, e ao mesmo tempo eram relegados à mais extrema miséria e à mais cruel exploração" (MOTA, 2003, p. 164).

Em carta a Coelho Neto, escreveu de Manaus:

[...] Vivo sem luz, meio apagado e num estoneamento. Nada te direi da terra e da gente. Depois, aí, e num livro: Um Paraíso Perdido, onde procurarei vingar a Hiloe maravilhosa de todas as brutalidades das gentes adoidadas que a maculam desde 0 século XVIII (in: GALVÃO; GALOTTI, 1997, p. 266).

No mesmo dia, escreveu também para José Veríssimo dando conta do projeto do livro, e pergunta ao amigo: "Acha bom o título 'Um Paraíso Perdido' para o meu livro sobre a Amazônia? Ele reflete bem o meu incurável pessimismo, mas como é verdadeiro?!" (in: GALVÃO; GALOTTI, 1997, p. 269).
Referindo-se ao livro em carta ao amigo Escobar, Euclides afirma que está alinhando "as primeiras páginas de Um Paraíso Perdido, o meu segundo livro vingador. Se o fizer, como o imagino, hei de ser (perdoa-me a incorrigível vaidade) hei de ser para a posteridade um ser enigmático, verdadeiramente incompreensível entre estes homens" (in: GALVÃO; GALOTTI, 1997, p. 306).

À semelhança da maneira como se referira a Os Sertões, Euclides lança mão da expressão linguística "livro vingador" para atualizar a metáfora conceptual escrita como vingança.

Percebe-se que as metáforas desse tipo apresentam um conceito ao estruturar um termo $X$ em termo de um outro termo $Y$, como: $X$ SER $Y$. E nessa estrutura, $\mathrm{X}$, sendo introduzido em termo de $\mathrm{Y}$, pode ser compreendido mais facilmente. Silva (2009, p. 106), comentando essa estrutura, explica que "o conteúdo e o sentido de $Y$ já estão na cultura, na memória social, de modo que $Y$ tem o papel de dar sentido à experiência que $X$ mostra". Por esse prisma, o papel dessa metáfora é o

"de sancionar ações; de justificar as inferências para se entender o significado ali estabelecido; de auxiliar a estabelecer as metas do entendimento, propostas pelos interlocutores, participantes, diante da atividade que fomentam; e de trazer mudanças culturais, conforme as tendências socioculturais e sociopolíticas, isto pela introdução dos novos conceitos estabelecidos pelas metáforas (SILVA, 2009, p. 106).

Dessa forma, a metáfora VINGAR-SE É ESCREVER, verbalizada nas expressões "livro vingador" e "segundo livro vingador" (referentes a Os Sertões e a Um Paraíso perdido, respectivamente) sanciona a concepção euclidiana de que uma vingança era necessária tanto no caso do sertão nordestino quanto no caso dos rincões amazônicos. Uma vingança em nome dos que não tinham condições de se vingar: sertanejos massacrados e seringueiros, também sertanejos, escravizados. Portanto, essa metáfora, longe se ser apenas um recurso de ornamento linguístico, como pretenderiam alguns clássicos retóricos, traz a lume uma visão de mundo enraizada na cultura em que o autor se insere. 
Mas no caso da Amazônia, infelizmente o projeto do "segundo livro vingador" não foi concluído, devido a uma série de fatores ligados à vida do autor, especialmente a sua morte prematura. $\mathrm{O}$ que restou do projeto do segundo livro vingador de Euclides foi uma série de artigos, reunidos postumamente sob o título À Margem da história, que constituíam o esboço de Um Paraíso Perdido.

Evidentemente, não tendo o projeto do livro se completado, não se tem como avaliar o projeto. Todavia, é possível avaliar os textos esparsos publicados em jornais, além daqueles de À Margem da história, que certamente fariam parte do grande livro ansiado. São "apenas algumas páginas sobre aspectos da vida amazônica, ligados à terra, às águas, ao clima e ao homem, que ficaram para sempre inacabadas. Ainda desta vez, a Amazônia não teria o seu grande livro" (RABELLO, 1966, p. 279).

\section{Metáfora "Um livro é um filho"}

Numa carta de Manaus endereçada ao pai, Manuel Pimenta da Cunha, no dia 30 de dezembro de 1904, Euclides escreveu: "[...] Em todos os portos onde saltei fui gentilmente recebido graças à influência do seu grande neto - Os Sertões. Realmente, nunca imaginei que ele fosse tão longe" (in: GALVÃO; GALOTTI, 1997, p. 249).

Percebe-se nessa passagem a materialização linguística da metáfora conceptual UM LIVRO É UM FILHO, equivalente a: o meu livro, sendo meu filho, é neto de meu pai.

E essa metáfora se refina ainda mais quando se pensa que um livro é um filho do espírito, como expressou Euclides em carta a D. Agustín de Vedia, nos seguintes termos: "Os Sertões [...] é 0 primogênito do meu espírito, e há críticos atrevidos que afirmam ser o meu único livro... Será verdade? Repugna-me, entretanto, admitir que tenha chegado a um ponto culminante, restando o resto da vida para descê-lo" (in: GALVÃO; GALOTTI, 1997, p. 384 grifo meu).
Parece certo que Euclides, aqui, dialoga com o princípio da "maiêutica", estabelecido por Sócrates no século IV a.C. O filósofo ateniense engendrou uma interessante associação do conhecimento com o fenômeno humano do parto, e a partir daí metaforizou a busca do conhecimento e da verdade como um parto, qual seja o "parto das ideias", que é o significado grego para a palavra "maiêutica" (CHAUí, 1995; COTRIM, 1997).

Observando atentamente a profissão de sua mãe como parteira, Sócrates deduziu que ocorre com o conhecimento um processo semelhante ao que ocorre com o parto: Primeiramente, vêm as "dores do parto", quando o indivíduo põe em xeque o seu próprio conhecimento sobre alguma coisa e se põe a perguntar; depois dessa fase de incertezas e questionamentos, ocorre o nascimento de uma nova ideia, um novo ponto de vista a respeito do assunto. Baseado nessa analogia, Sócrates passou a utilizar o termo "maiêutica" para se referir ao "parto das ideias", ou seja, o nascimento de ideias complexas a partir de questões simples. A maiêutica, então, é um processo de reconstrução de um conceito, em que o indivíduo vai revisando e reelaborando suas noções até chegar ao conceito verdadeiro por aproximações (CHAUÍ, 1995; COTRIM, 1997).

O método da maiêutica consiste em perguntar, questionar o que se sabe, com vistas a saber mais. Os questionamentos, muitas vezes, acabam por convencer o indivíduo da esterilidade de suas reflexões, levando-o a admitir seu equívoco. E dessa descoberta vem à luz uma nova vida (ideia). Sócrates via esse processo como uma engenhosa obstetrícia do espírito, que facilitava a parturição das ideias. A verdade é algo que é parido, num parto intelectual. Mas o trabalho de continuar perguntando e continuar encontrando dificuldades, em busca de novas descobertas, na decifração de novos mistérios, é um processo que não cessa nunca (ARANHA e MARTINS, 1992; CHAUÍ, 1995; COTRIM, 1997).

Esse parece ser o caso de Euclides em seus livros-filhos, nascidos do seu espírito: eles vieram à luz num doloroso processo de evolução de ideias. Tanto no caso dos sertões baianos quanto no caso 
dos "desertos" amazônicos, Euclides se aproxima do lugar com um "olhar" prévio, gestado a partir das muitas leituras que anteriormente fizera. Mas ao sair dos livros e pôr os seus próprios pés no chão desconhecido para aos poucos conhecê-lo, sofre sempre um choque de realidade, responsável pelo desencadeamento de uma série de perguntas e questionamentos que fazem ruir o edifício de certezas que edificara em sua cabeça. E os livros nascem no berço dessas angustiantes dúvidas que geram luminosas (e não menos inquietantes) descobertas. Segundo Euclides deixa claro a amigos e familiares em suas cartas, foi o que aconteceu na escrita de Os sertões e também na projeção de Um paraíso perdido, que infelizmente foi um projeto que não se completou porque, ainda em plenas dores de parto, a morte prematura colheu o seu autor.

\section{Considerações finais}

$\mathrm{Na}$ introdução deste trabalho, me propus refletir, nos limites da natureza da pesquisa, sobre as metáforas metalinguísticas de Euclides da Cunha, em ensaios do escritor e em cartas que ele escreveu a amigos e familiares, de certo modo "escriturando" a sua escrita. Euclides foi, de fato, um grande metaforista, considerando metaforista a pessoa que utiliza metáfora com frequência em seus discursos. As metáforas residem em praticamente todos os seus textos, não apenas os ficcionais mas igualmente os pretensamente não ficcionais, como as inúmeras cartas endereçadas a amigos e familiares e os relatórios técnicos que frequentemente escrevia, em razão do ofício de engenheiro. A cada página, o leitor vai "saboreando" (para usar um termo da lavra de Aristóteles) metáforas, sejam estruturais, sejam orientacionais, sejam ontológicas - utilizo agora termos propostos por Lakoff e Johnson (2002).

Ao falar sobre seus livros, Euclides acionou o domínio-fonte da escrita para atualizar o domínio-alvo da vingança contra a estupidez humana observada tanto nos sertões da Bahia quanto nos seringais amazônicos. Estupidez que se materializava na carnificina promovida pelo governo contra a gente miserável no sertão e na escravização do sertanejo, igualmente miserável, na selva equatorial. Os livros Os sertões e Um paraíso perdido seriam os veículos dessa vingança.

Ele aciona também o domínio-fonte da maternidade/paternidade para atualizar o domínioalvo dos seus livros, primordialmente Os sertões, encarando a feitura de um livro como um parto e todas as suas contingências, tanto dolorosas quanto prazerosas, porque para ele um livro é um filho do espírito.

Como se vê, estruturando $X$ em termo $Y(X$ SER $Y$ ), Euclides transferiu para $X$, em cada metáfora, uma série de concepções, conceitos, crenças, etc., relativos a $\mathrm{Y}$. Assim, $\mathrm{X}$ poderia ser mais facilmente compreendido, já que o sentido e o conteúdo de $Y$ estão bem assentados na memória cultural e social. Portanto, as imagens da escrita e de um parto (conteúdos de $\mathrm{Y}$ ) permitem perfeitamente compreender melhor as ideias de vingança e escrita de um livro, respectivamente (ideias de X). Dessa forma, lendo as metáforas metalinguísticas de Euclides pela ótica da teoria conceptual, assumo, juntamente com Lakoff e Johnson, que, longe de ser uma questão apenas de linguagem, a metáfora é também - e fundamentalmente - uma questão de pensamento e ação.

\section{Referências}

ABREU, Regina. O enigma de Os Sertões. Rio de Janeiro: Funarte: Rocco, 1998. 410 p.

ARANHA, Maria Lúcia de Arruda. MARTINS, Maria Helena Pires. Temas de Filosofia. São Paulo: Moderna, 1992.

BARTHES, Roland. Crítica e Verdade. São Paulo: Perspectiva, 1970.

CHALHUB, Samira. A Metalinguagem. São Paulo: Ática, 2002. $88 \mathrm{p}$.

CHAUÍ, Marilena. Convite à Filosofia. São Paulo: Ática, 1995.

COTRIM, Gilberto. Fundamentos da Filosofia - Ser, Saber e Fazer. São Paulo: Saraiva, 1997. 
CUNHA, Euclides da. Amazônia - um paraíso perdido. Manaus: Valer; Governo do Estado do Amazonas; EDUA, 2003. 379 p.

FRANCISCO, Domingos. Metáfora da plenitude. A heteronímia pessoana à luz da teoria da metáfora de Paul Ricoeur. Lisboa: Dissertação de Mestrado apresentada à Faculdade de Letras da Universidade de Lisboa, 2001.

GALVÃO, Valnice Nogueira; GALOTTI, Oswaldo. Correspondência de Euclides da Cunha. São Paulo: EDUSP, 1997. 355 p.

GONDIM, Neide. A Invenção da Amazônia. São Paulo: Marco Zero, 1994.

JAKOBSON, Roman. Linguística e comunicação. 22. ed. São Paulo: Cultrix, 2010. 207 p.

LAKOFF, George \& JOHNSON, Mark. Metáforas da vida cotidiana [Coordenação de tradução Mara Sophia Zanotto]. Campinas, SP: Mercado das Letras; São Paulo: WDUC, 2002 (Coleção As Faces da Linguística Aplicada). 360 p.

MOTA, Lourenço Dantas. Euclides da Cunha. São Paulo: Editora Três, 2003 (A Vida dos Grandes Brasileiros, 11) 186 p.

RABELLO, Sylvio. Euclides da Cunha. 2. ed. Rio de Janeiro: Civilização Brasileira, 1966 (Coleção Vera Cruz, Literatura Brasileira, vol. 103). 370 p.

REIS, Arthur Cézar Ferreira. História do Amazonas. 2. ed. Belo Horizonte: Itatiaia, 1998. 262 p.

SILVA, Sônia Maria Cândido da. Construções metafóricas conceptuais atualizadas em crônicas dos séculos XIX e XX. Tese de Doutorado apresentada Universidade Federal da Paraíba. João Pessoa: UFPB, 2009.

SOUZA, Márcio. História da Amazônia. Manaus: Valer, 2009. 399 p.

TELES, Gilberto Mendonça. A Escrituração da Escrita. Petrópolis: Vozes, 1996. 